\title{
STRATEGI PENGEMBANGAN SUMBER DAYA MASYARAKAT KEPULAUAN YANG UNGGUL MENUJU SOCIETY 5.0
}




\section{BIODATA}

\section{IDENTITAS}

Nama: Dr. Shermina Oruh, S.K.M, DESS

TTL: Makassar, 11 September 1968

Jenis Kelamin: Perempuan

NIP 196809111993022003

S3-Universitas Negeri Makassar

S2-Universitas Montpellier, Prancis

S1-Universitas Hasanuddin, Makassar

$\checkmark$ Dosen Universitas Pejuang Republik Indonesia, Makassar $\checkmark$ Staf Pengajar pada Universitas Negeri Makassar $\checkmark$ Kabid. Diklat, Litbang \& Etika, RSUD Haji Mks (Nov. 2020-Okt, 2021)

$\checkmark$ Kabag. Program \& Informasi, RSKD Dadi Prov. Sulsel (2011-2020)

$\checkmark$ Kasubag. Program, Dinas Kesehatan Prov. Sulsel (2007-2011)

$\checkmark$ Staf Puskesmas Labakkang, Kab. Pangkep (1993-2007)

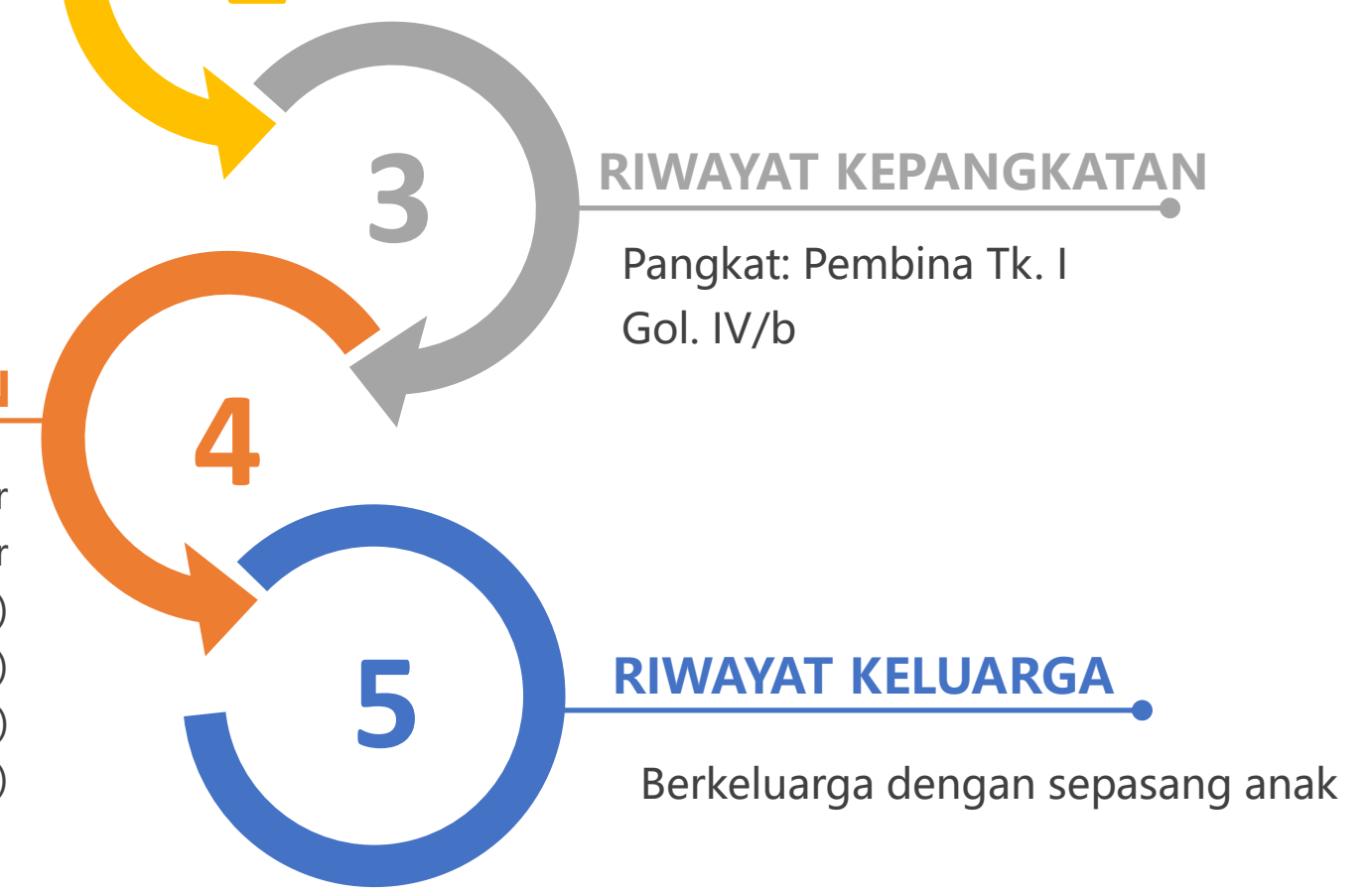




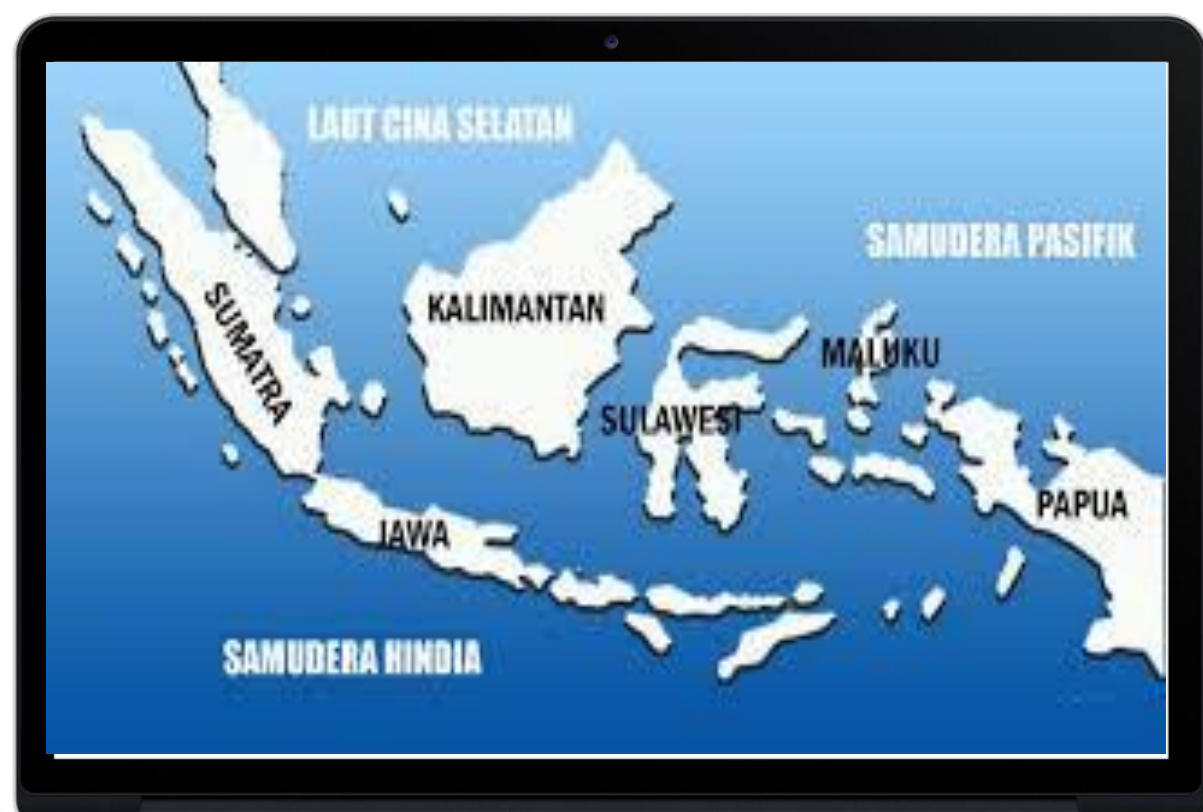

밈

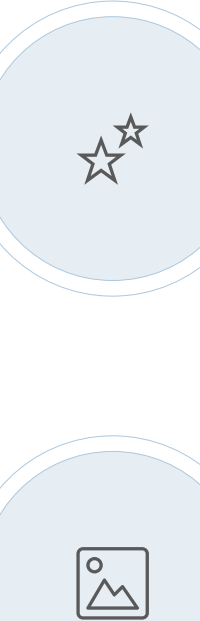

INDONESIA ADALAH NEGARA KEPULAUAN

(ARCHIPELAGO STATE) TERBESAR DI DUNIA DENGAN 2/3 WILAYAHNYA ADALAH LAUTAN

DENGAN POTENSI FISIK SEBESAR INI, INDONESIA DIKARUNIAI PULA DENGAN SUMBERDAYA PERIKANAN DAN KELAUTAN YANG BESAR

DARI SISI KEANEKARAGAMAN HAYATI, INDONESIA DIKENAL SEBAGAI NEGARA DENGAN KEKAYAAN HAYATI KELAUTAN TERBESAR 


\section{PERKEMBANGAN SOCIETY}
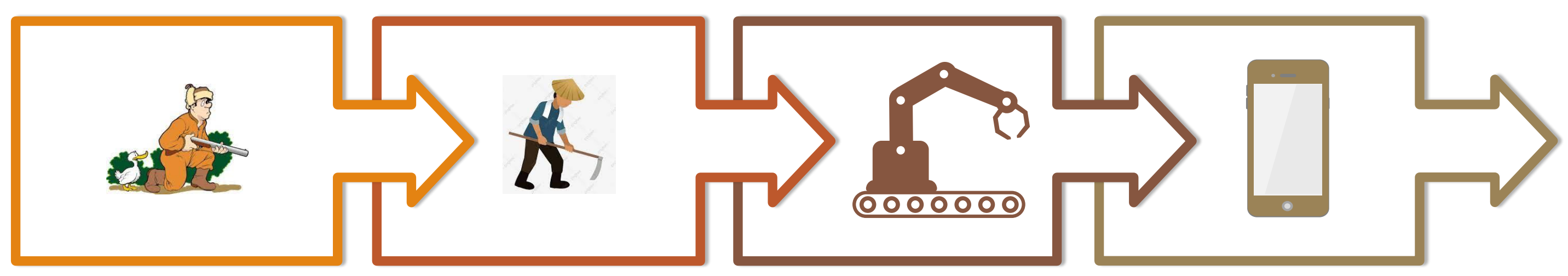

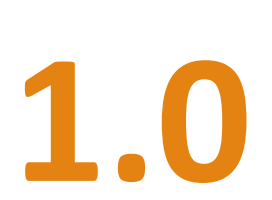

SOCIETY 1.0 = Masyarakat Berburu

Manusia masih berada di era berburu dan mengenal tulisan... ABAD 18

SOCIETY 2.0 $=$ Masyarakat Agraris

2.0
Era pertanian di mana manusia sudah mulai mengenal bercocok tanam... ABAD 19

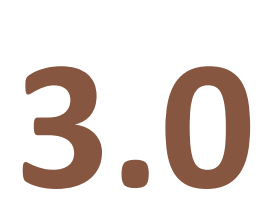

SOCIETY 3.0 = Masyarakat Industri

Sudah memasuki era industri, yaitu ketika manusia sudah mulai menggunakan mesin untuk menunjang aktivitas sehari-hari...ABAD 20

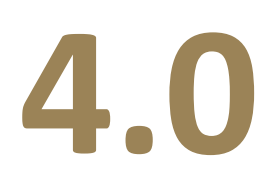
SOCIETY 4.0 = Masyarakat Informasí

Sering disebut era revolusi industry 4.0 yang kita alami saat ini, yaitu manusia yang sudah mengenal teknologi komputer hingga internet atau teknologi digital serta penerapannya di dalam kehidupan sehari-hari...ABAD 21 


\section{SOCIETY 5.0}

\section{About Society}

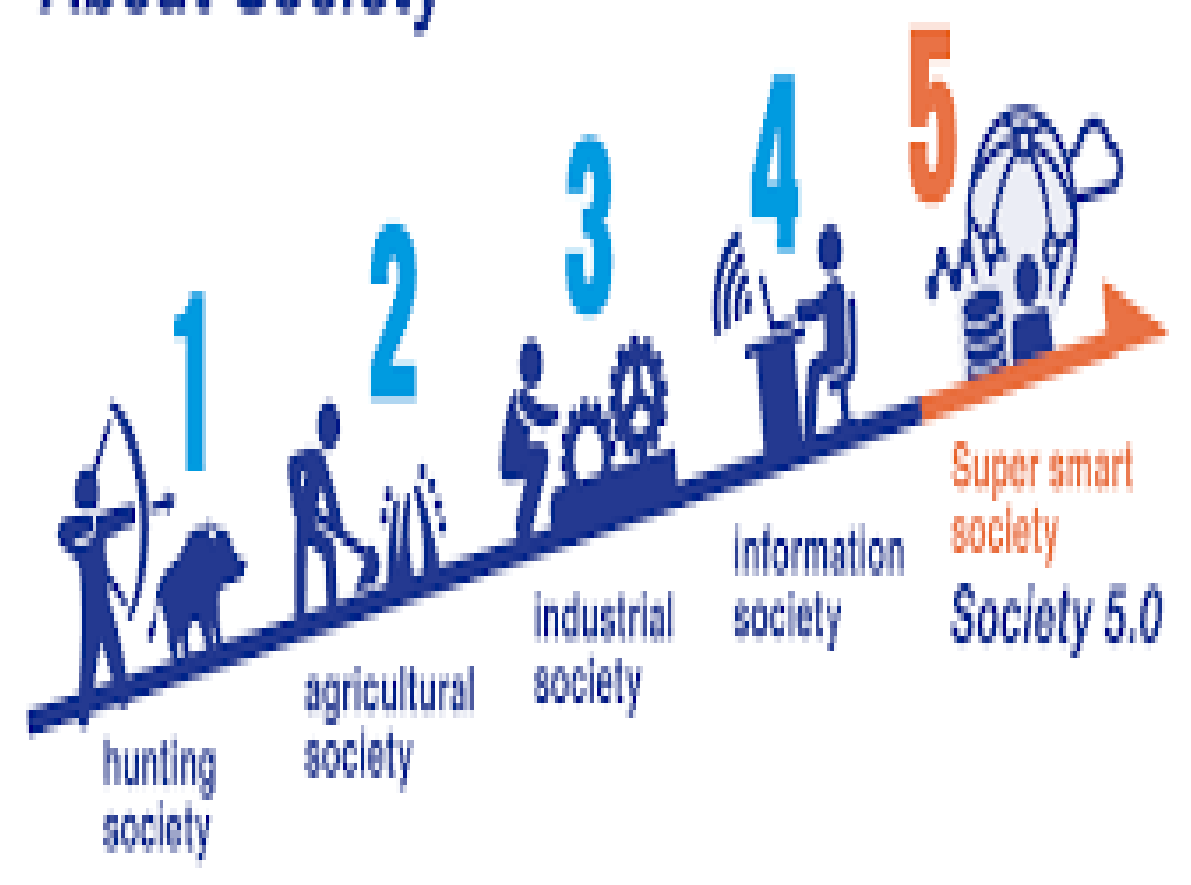

$\square$ Society 5.0 di gagas oleh Negara Jepang dan diresmikan 2 tahun yang lalu, pada 21 Januari 2019

$\square$ Society 5.0 dibuat sebagai resolusi atas resolusi industri 4.0 yang dinilai berpotensi mendegradasi peran manusia.

$\square$ Society atau Masyarakat 5.0 adalah suatu konsep masyarakat yang berpusat pada manusia dan berbasis teknologi.

$\square \quad$ Konsep Society 5.0 merupakan penyempurnaan dari konsep-konsep yang ada sebelumnya. 


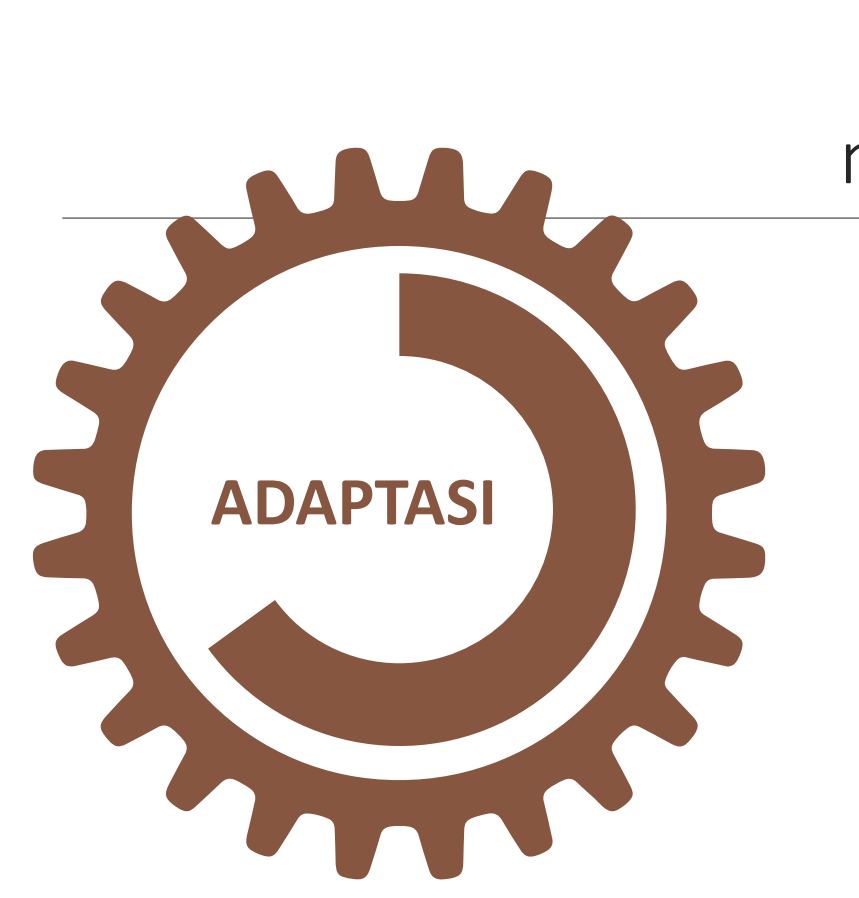

ADAPTASI

Beradaptasi dengan Society 5.0, perlu mengetahui perkembangan para generasi kita, mulai dari generasi milenial sampai dengan generasi kolonial di mana banyak sekali terjadi transformasi peradaban antar generasi tersebut.
Hal yang harus dilakukan dalam menghadapi Era Society 5.0 yaitu:
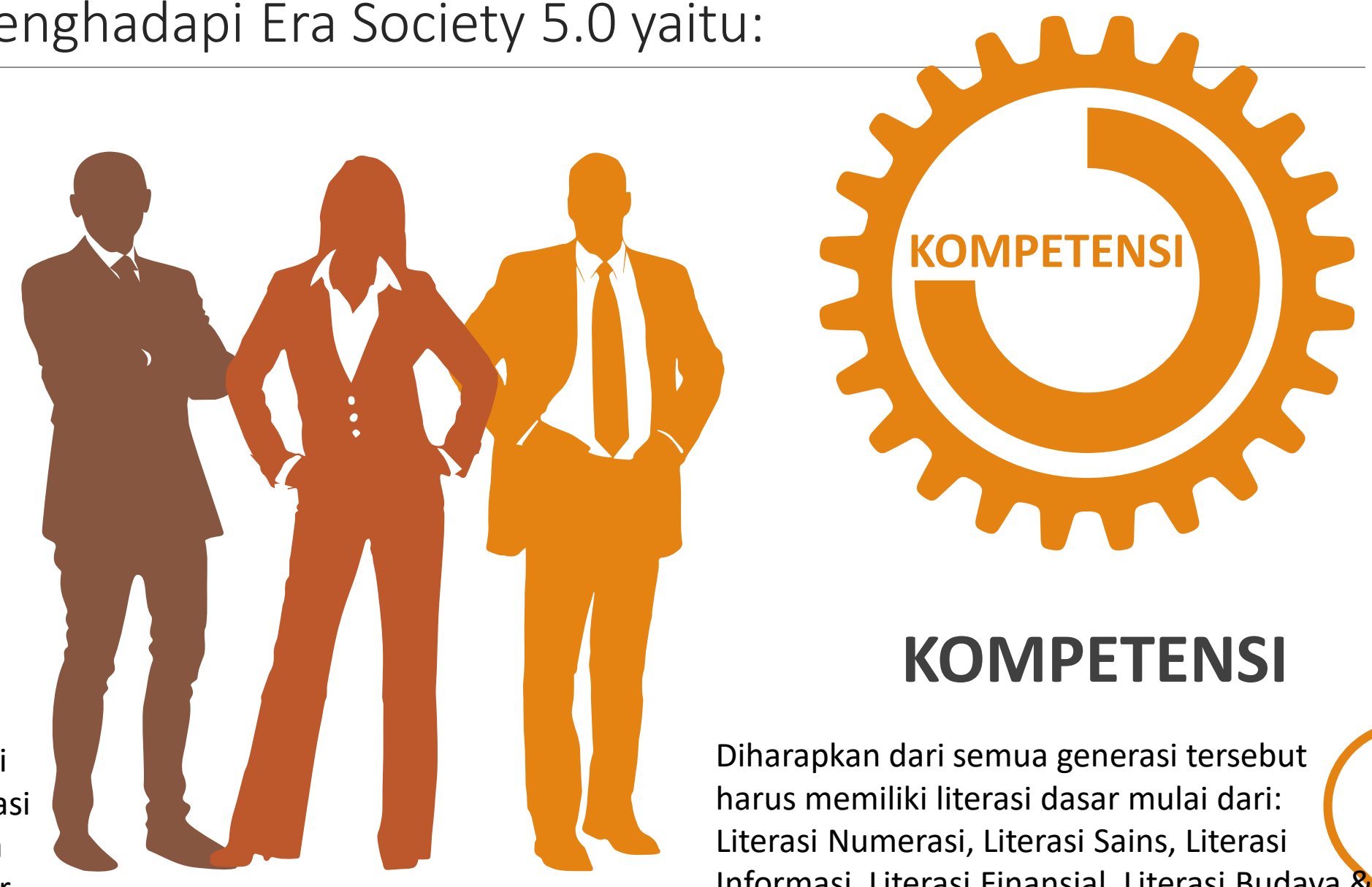

KOMPETENSI

Diharapkan dari semua generasi tersebut harus memiliki literasi dasar mulai dari: Literasi Numerasi, Literasi Sains, Literasi Informasi, Literasi Finansial, Literasi Budaya \& Kewarganegaraan 


\section{Hal lain yang bisa dipersiapkan dalam rangka menyongsong Era Society 5.0 yang berkaitan dengan peningkatan kompetensi sumber daya manusia antara lain adalah:}

\begin{abstract}
Mengikuti Perkembangan Zaman
dgn baik

Dengan mengikuti perkembangan zaman, bisa memberikan pelayanan kepada masyarakat dengan semakin
\end{abstract} baik

Kemampuan berbahasa Asing

Memudahkan seseorang untuk terhubung dengan dunia yang luas guna menyongsong Era Society 5.0

\section{Keahlian Literas}

Mengarah ke era serba digital. Penerapan literasinya pun harus sesuai orientasi, antara literasi lama dan literasi baru sehingga capaiannya dapat secara simultan dan terpadu.

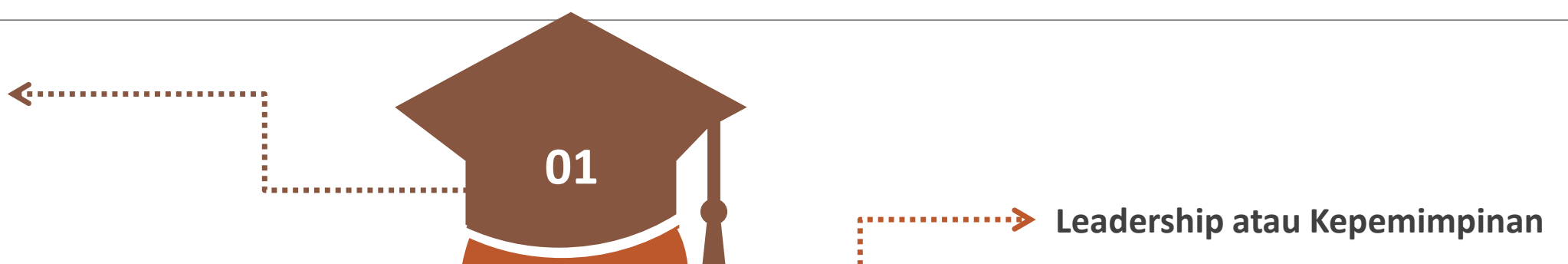

Sikap kepemimpinan yang adaptif dan informatif diselingi dengan nilai spiritual

\section{Menguasai Teknologi IT}

Pekerjaan dan aktivitas manusia akan difokuskan pada HumanCentered yang berbasis pada teknologi. 


\section{BAGAIMANA STRATEGI MASAYARAKAT KEPULAUAN}

PANDEMI COVID-19

Sedang berjalan
ERA SOCIETY 5.0

Akan berjalan

Disadari atau tidak, Pandemi Covid-19 mengantar kita berjalan menuju Era Sosiety 5.0.

Kebijakan Work From Home (WFH) dan Work From Office (WFO) melatih kita menggunakan teknologi informasi dalam segala bidang.

PERTANYAAN KRITISNYA SEBERAPA SIAP MASYARAKAT KEPULAUAN MENUJU ERA SOCIETY 5.0 DAN BAGAIMANA STRATEGI PENGEMBANGANNYA? 


\section{STRATEGI PENGEMBANGAN}

$\square$ Strategi adalah pendekatan secara keseluruhan yang berkaitan dengan pelaksanaan gagasan, perencanaan, dan eksekusi sebuah aktivitas dalam kurun waktu.

$\square$ Strategi pengembangan, bertanya \& menjawab 3 pertanyaan dasar berikut ini :

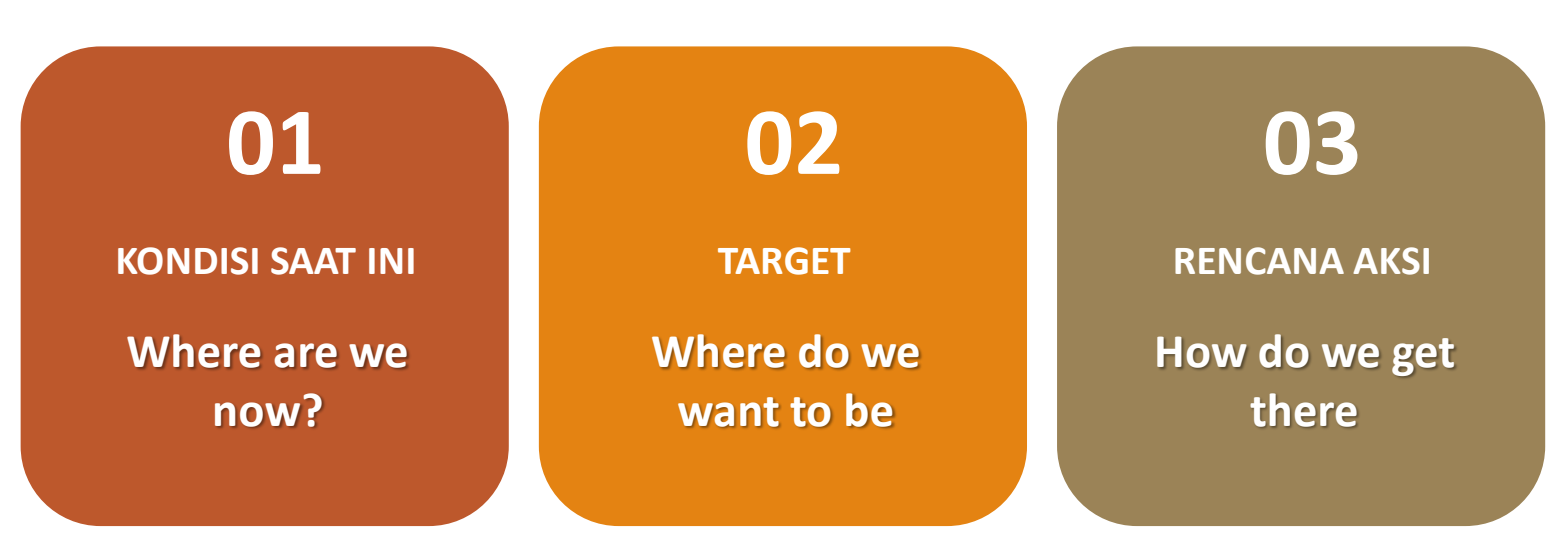




\section{WHERE ARE WE NOW?}

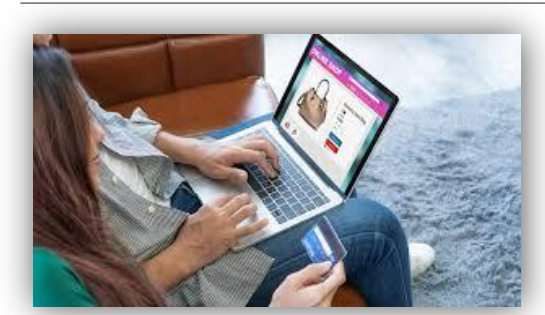

Transaksi Digital dimana saja \& kapan saja

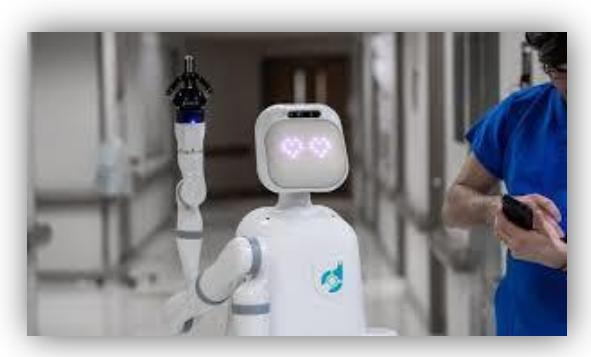

Robot Nurse

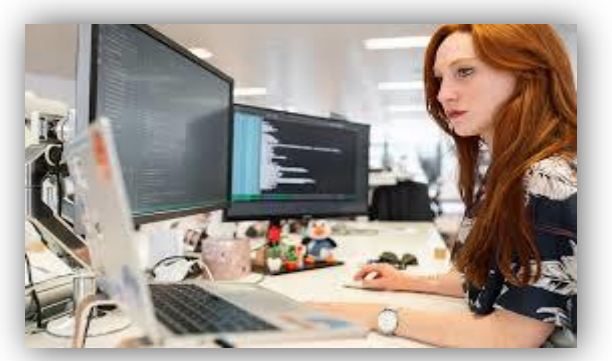

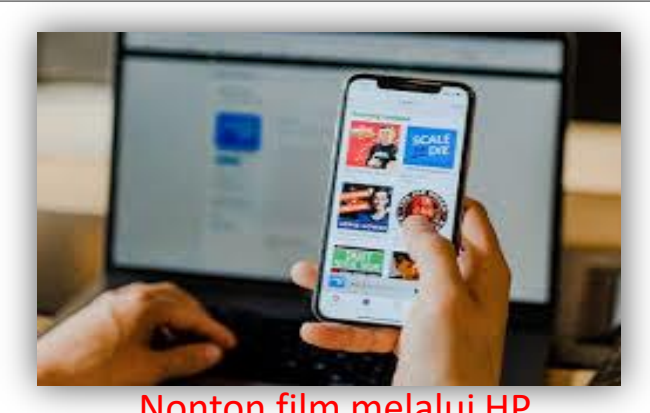

Nonton film melalui HP

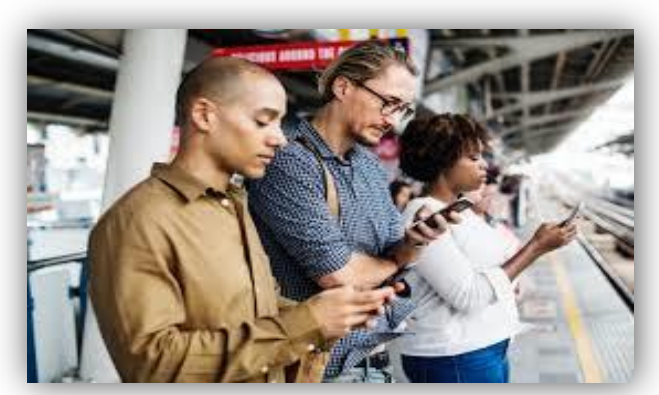

Individualistis

Akses data \& informasi pd saat yg sama

\section{Society 4.0}

Information

Society

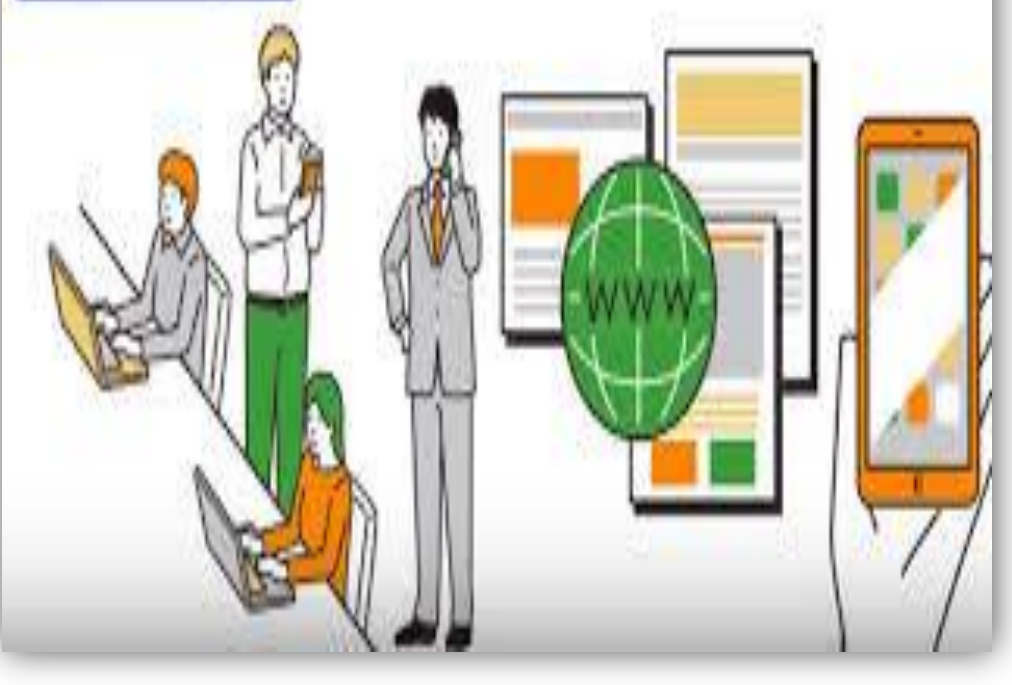




\section{WHERE ARE WE NOW?}

Melihat kondisi saat ini secara INTERNAL melalui kekuatan (Strength) dan kelemahan (Weakness) yang dimiliki masy kepulauan.

Tujuannya: mereposisi dan memantapkan kembali pentingnya mewujudkan wilayah kepulauan yang mandiri, maju, kuat dan berbasiskan kepentingan daerah dan NKRI

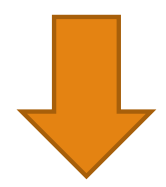

- Analisis kondisi Sumber daya manusia

- Analisis kondisi Sumber daya alam,

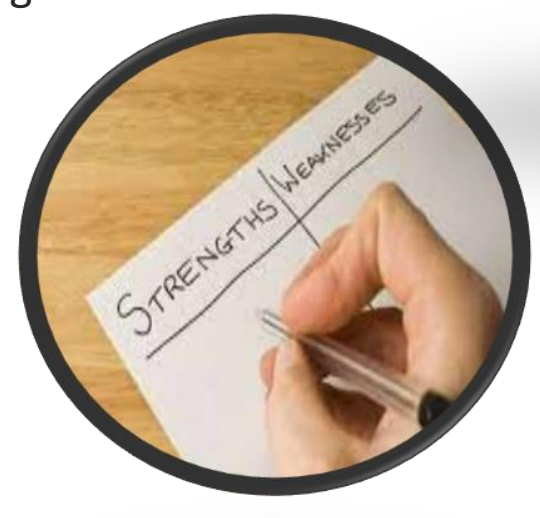

Mengetahui kondisi EKSTERNAL melalui peluang (Opportunities) dan ancaman (Threats) yang ada pada masyarakat kepulauan

Tujuannya: memperkuat dan mempertegas posisi dan status Indonesia sebagai negara kepulauan di dunia Internasional

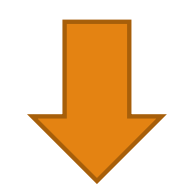

- Analisis Perda setempat

- Analisis Kebijakan Politik \& ekonomi

- Analisis Teknologi Informasi, dll

dll 


\section{WHERE DO WE WANT TO BE?}
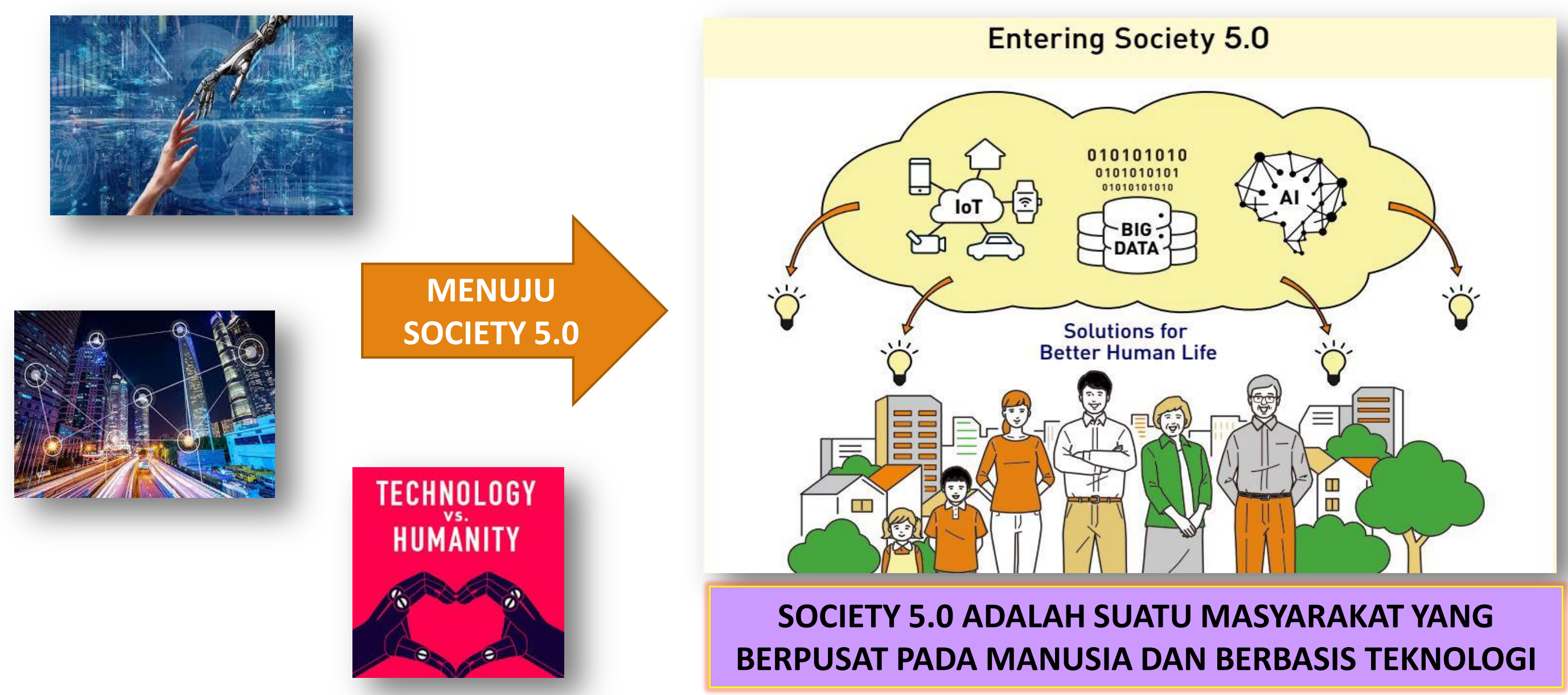


\section{HOW DO WE GET THERE?}

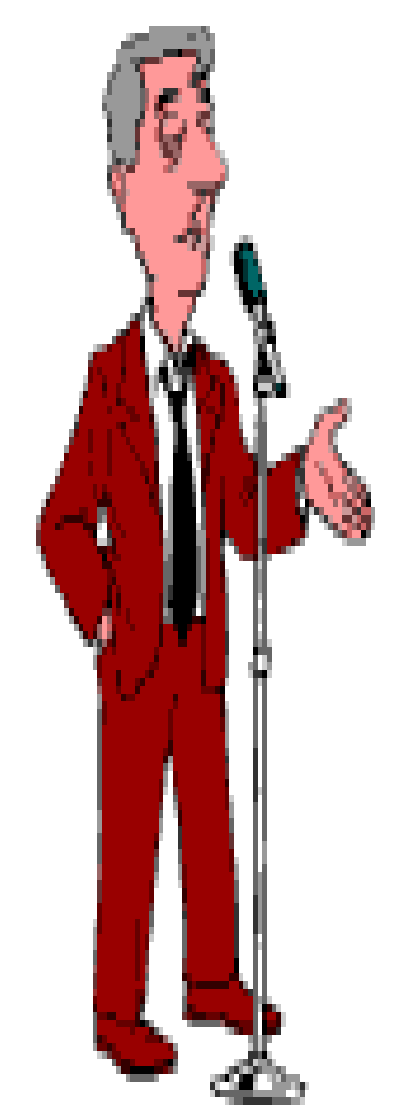

Untuk mencapai masyarakat kepulauan yang unggul dalam society 5.0 maka diperlukan pemetaan dari posisi

INTERNAL dan EKSTERNAL untuk menentukan STRATEGI apa yang dapat dikembangkan

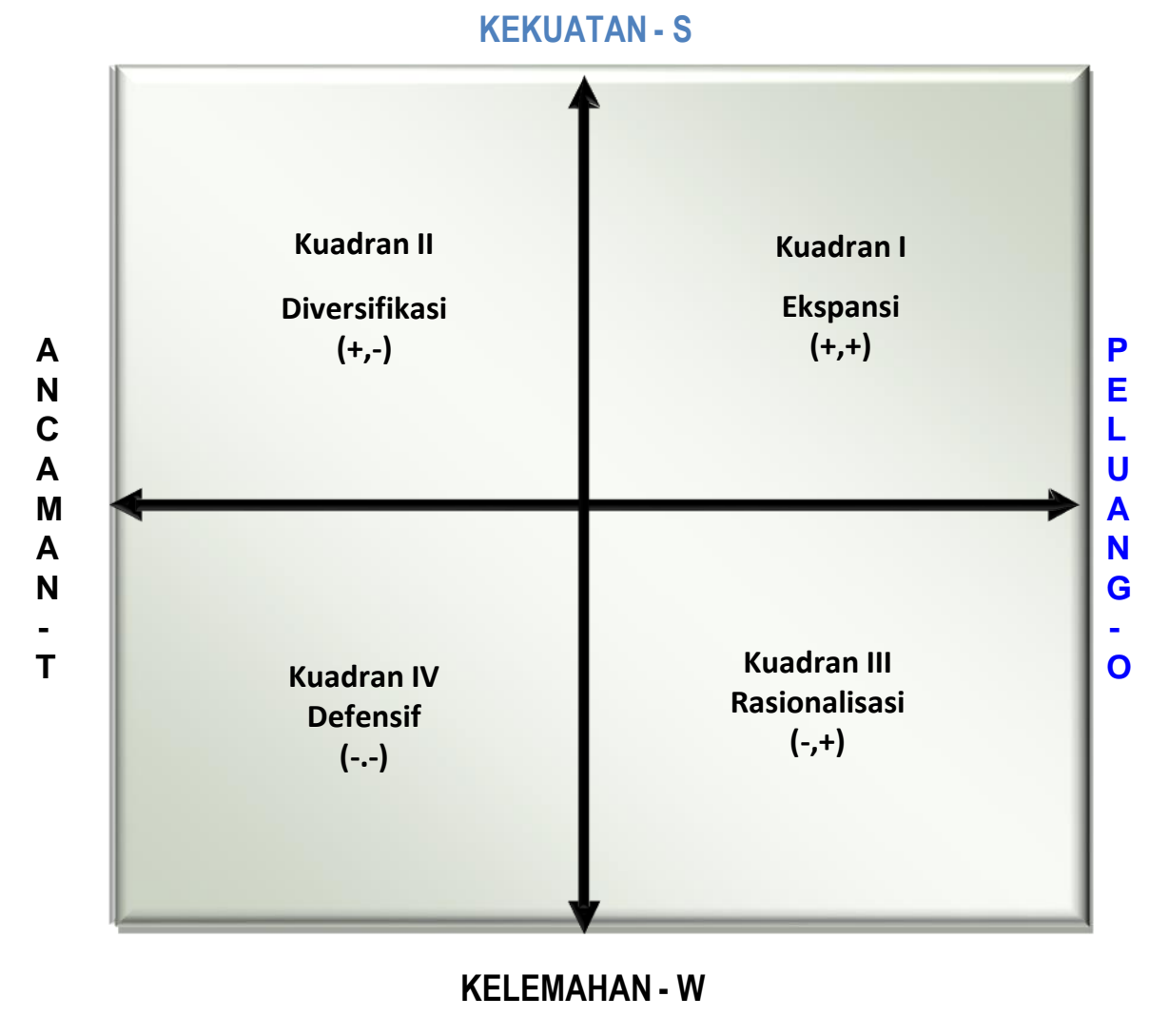




\section{KUADRAN I Strategi EKSPANSI/PROGRESSIF (strategi S-O)}

Merupakan posisi yang sangat menguntungkan karena dianggap memiliki keunggulan kompetitif

Organisasi mempunyai kekuatan (S) dan peluang (O) sehingga dapat memanfaatkan kekuatan dan peluang yang ada kearah ekspansi atau pengembangan, pertumbuhan, perluasan dalam bidang tertentu

Seyogyanya menerapkan strategi yang mendukung kebijakan pertumbuhan yang agresif 


\section{KUADRAN II \\ Strategi DIVERSIFIKASI (strategi S-T)}

Meskipun menghadapi berbagai ancaman, organisasi mempunyai keunggulan sumber daya

- Organisasi pada posisi seperti ini dapat menggunakan kekuatannya (S) untuk mencegah ancaman ( $\mathrm{T}$ )

Dilakukan melalui mobilisasi kekuatan dalam menciptakan diversifikasi, inovasi, pembaharuan, modifikasi di bidang tertentu dalam upaya mencegah ancaman. 


\section{KUADRAN III Strategi STABILITAS/RASIONALISASI/ Ubah Strategi (strategi W-O)}

- Organisasi menghadapi peluang (O) pasar yang besar tetapi sumber dayanya lemah (W)

Karena itu tidak dapat memanfaatkan peluang tersebut secara optimal untuk menciptakan stabilitas atau rasionalisasi atau melakukan investasi/divestasi dalam bidang tertentu

Fokus organisasi pada posisi seperti ini perlu meminimalkan kendala-kendala internal 


\section{KUADRAN IV Strategi DEFENSIF atau SURVIVAL (strategi W-T)}

Merupakan kondisi yang serba tidak menguntungkan

Organisasi menghadapi berbagai ancaman (T) eksternal sementara sumber daya yang dimiliki mempunyai banyak kelemahan (W)

Strategi yang diambil: defensive 


\section{HOW TO DO THAT?}

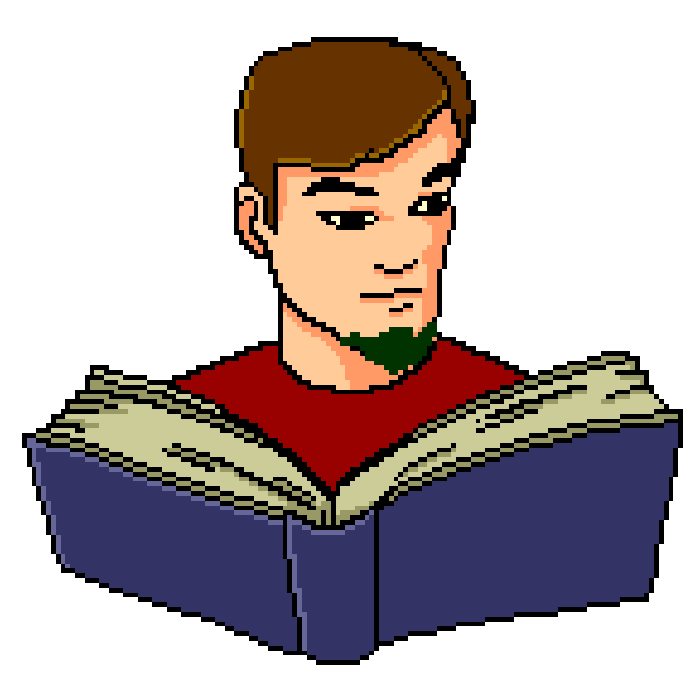

$\square$ Praktek pengembangan sosial atau manajemen pengembangan sosial lebih banyak memperhatikan pertemuan atau persentuhan dari berbagai pihak.

$\square$ Hal ini mengombinasikan berbagai macam pengetahuan dari berbagai interaksi yang melahirkan kolaborasi pengetahuan atau kolaborasi multipihak atau collaboration approach

$\square$ Dalam filosofi perencanaan yang baru, ditekankan bahwa perencanaan memiliki ciri kompleksitas, karena itu selalu melibatkan banyak pihak.

$\square$ Dengan demikian, harus di atasi atau dilibatkan banyak jenis pengetahuan

$\square$ Adapun dasar pemikirannya sbb: 


\section{REALITY}

- ORDER

- LINIER

- CERTAINTY

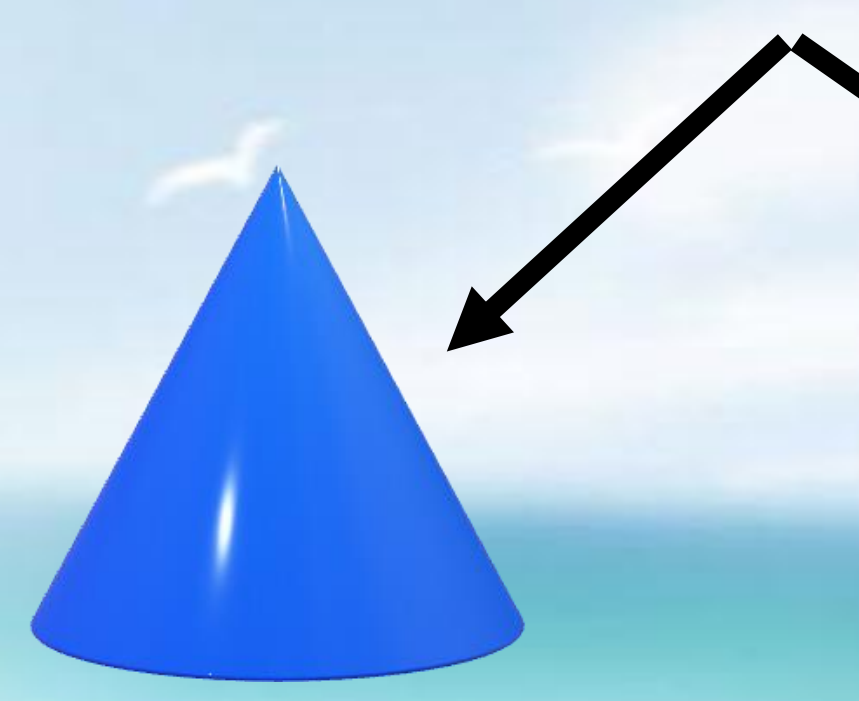

SIMPLICITY

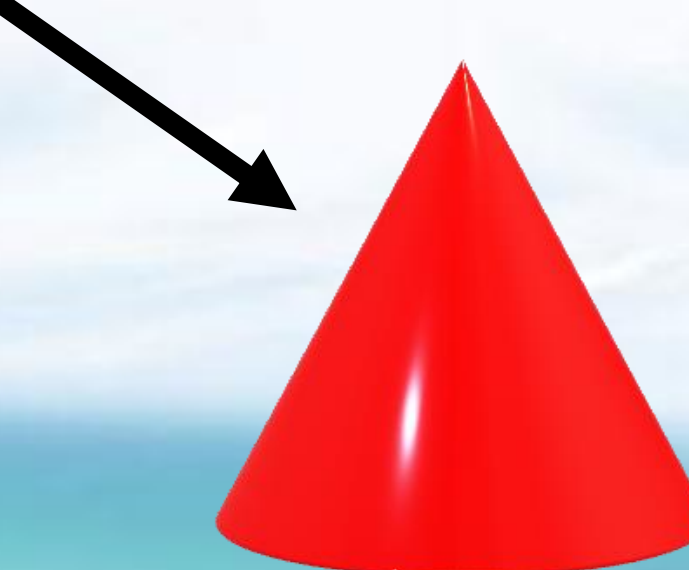

COMPLEXITY
Dalam abad 21, berkembang NEW SCIENCE bahwa tidak semua realitas bisa disederhanakan karena ada realitas yang sifatnya:

- DISORDER

- UNLINIER

- UNCERTAINTY Selalu membuat realitas kompleks. Dibutuhkan perencanaan yang kolaboratif. 
$\square$ COLLABORATIVE PLANNING adalah teori perencanaan yang mencoba mengaplikasikan ilmu baru (new science) yang dipelopori oleh Fritjof Capra dan Mulla Sadra.

$\square$ Karena realitas itu kompleks maka untuk mengelolanya tidak cukup dengan 1 pengetahuan atau 1 pihak saja, harus multi perspektif/multi knowledge/multi pihak/multi level.

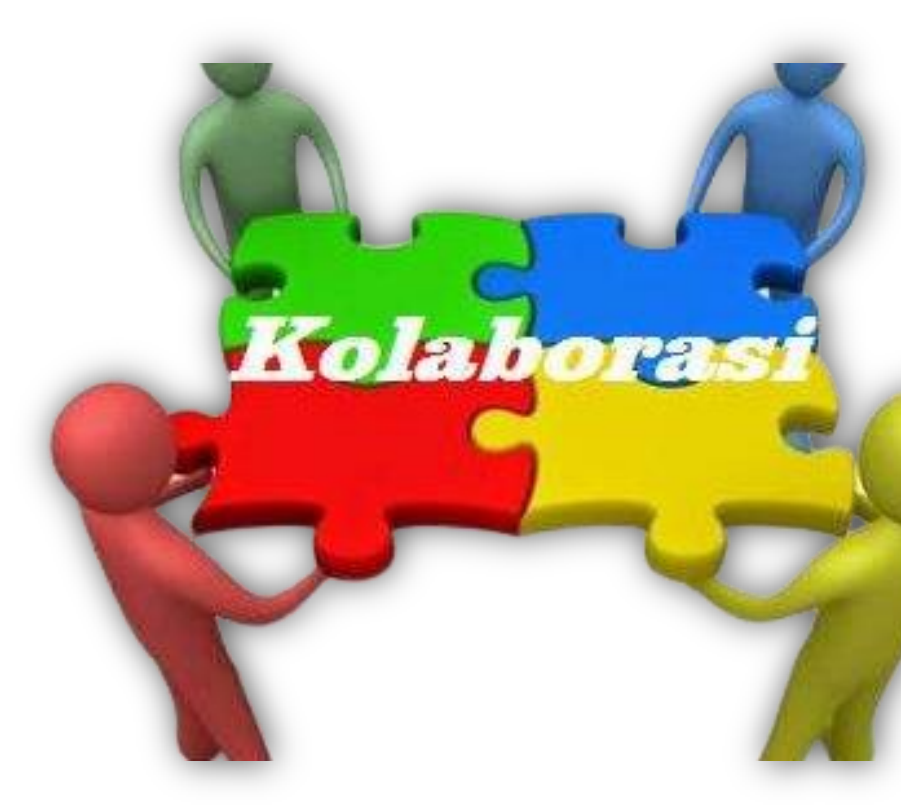


$\square$ Dalam memanage juga tidak bisa dibagi-bagi secara tunggal. Oleh karena itu, seluruh aktor dengan pengetahuannya masingmasing perlu difasilitasi untuk berkolaborasi.

- Asumsi dasarnya: Setiap pihak memiliki knowledge masing-masing, jika memiliki knowledge atau pengetahuan maka memiliki power atau kekuasaan. Setiap

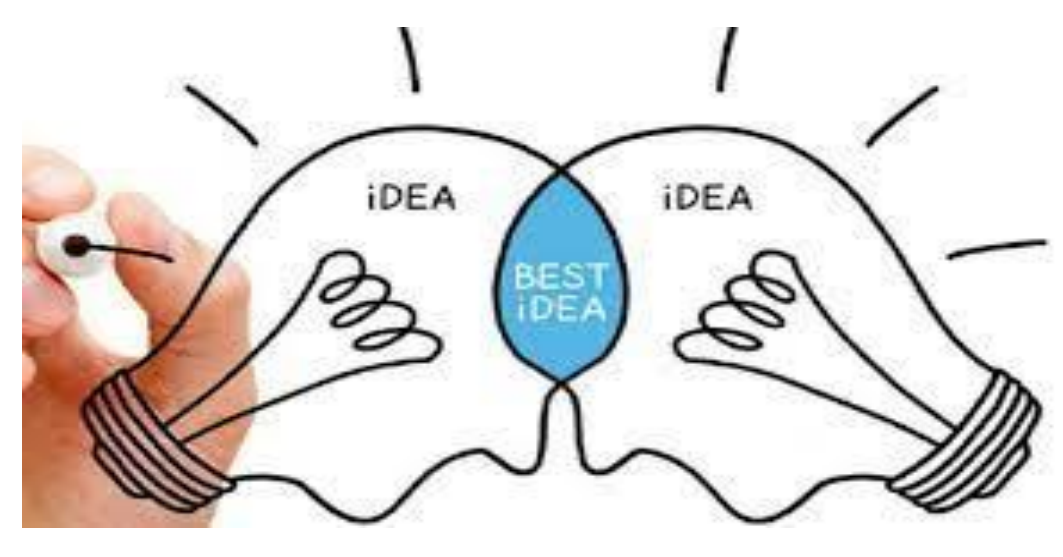
kuasa selalu memiliki landasan pengetahuan. 
Sumber knowledge/powernya terdiri dari unsur:

\section{NORM}

Merupakan aturan main (rule of the game)

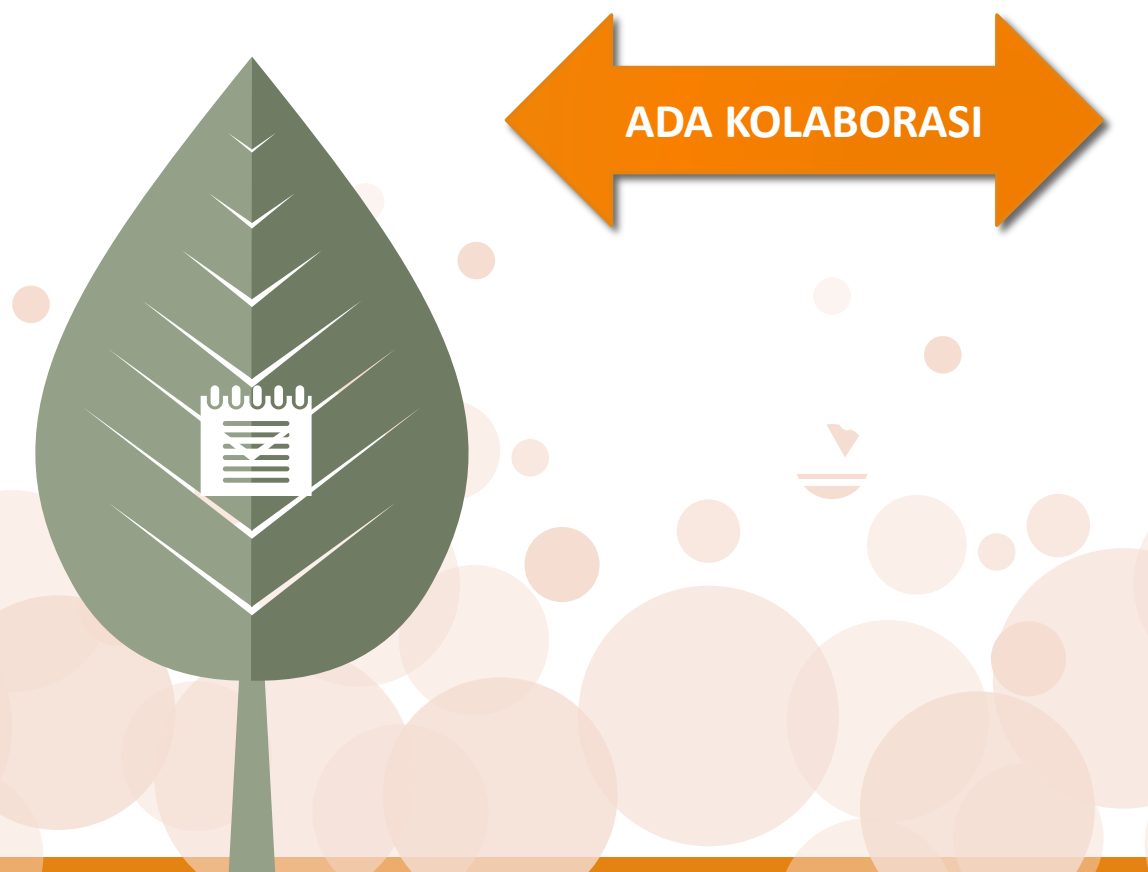

Ada aktor/pelaku yang mengelola

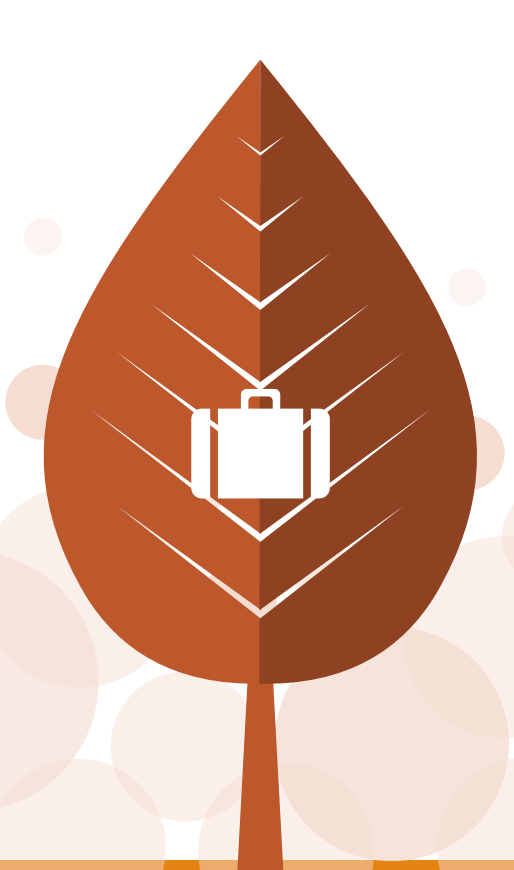

\section{RESOURCES}

Unsur yang di kelola

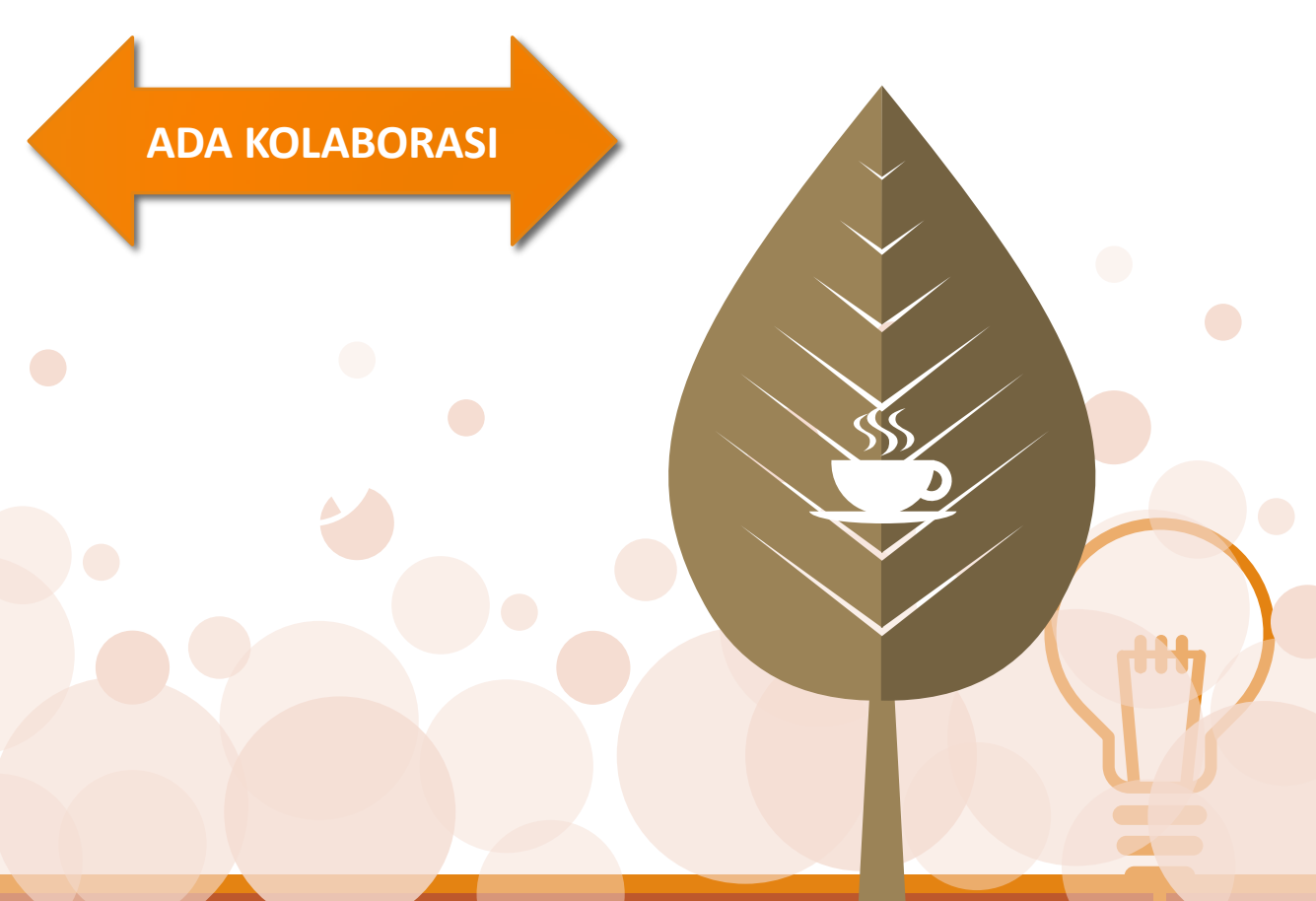




\section{Peran Penting Elemen dalam Rangka Menyongsong Era Society 5.0}

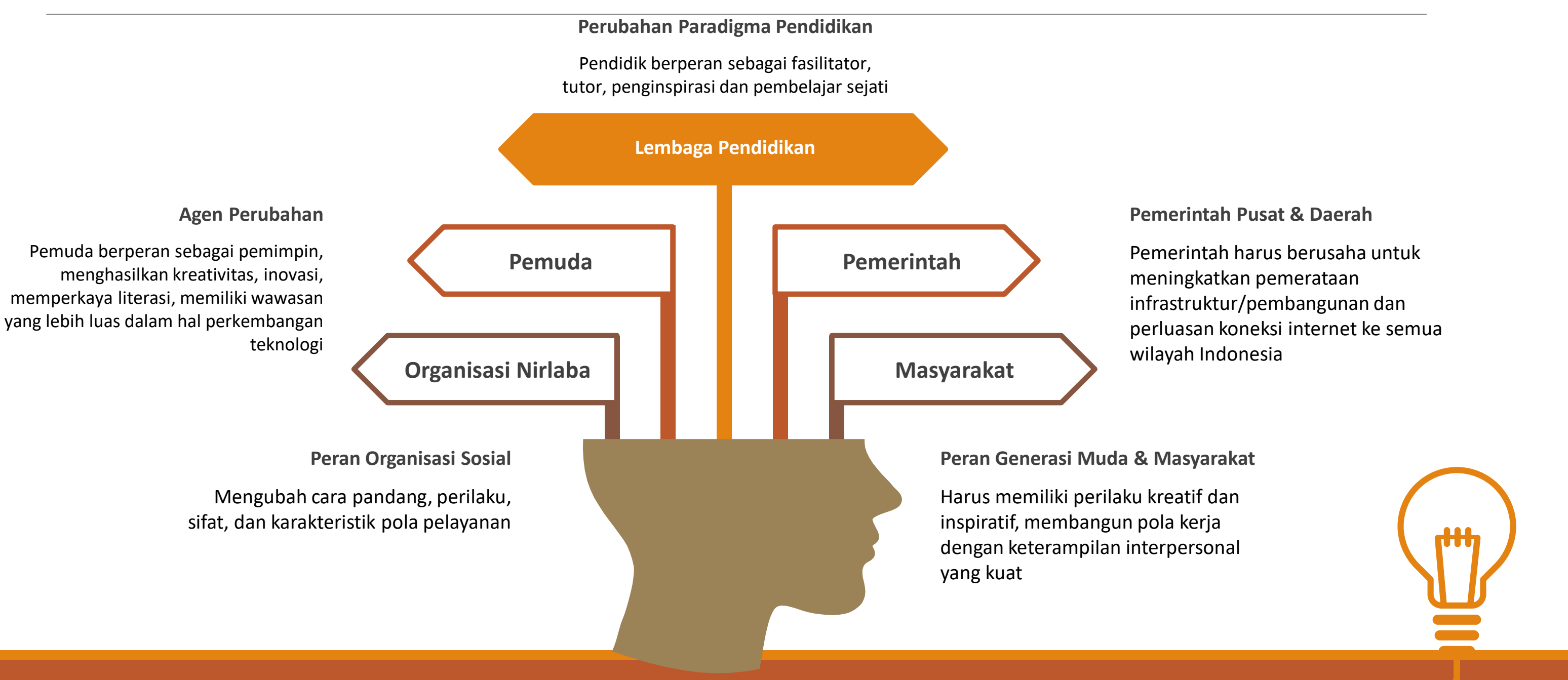




\section{ILUSTRASI}

Raja bertanya kepada Pejabatnya, "Mengapa di dunia ini hanya ada kambing yg berkelompok tetapi tidak ada anjing yang berkelompok!"
Pejabat yang pandai tidak langsung menjawab pertanyaan raja tetapi dia melakukan percobaan 

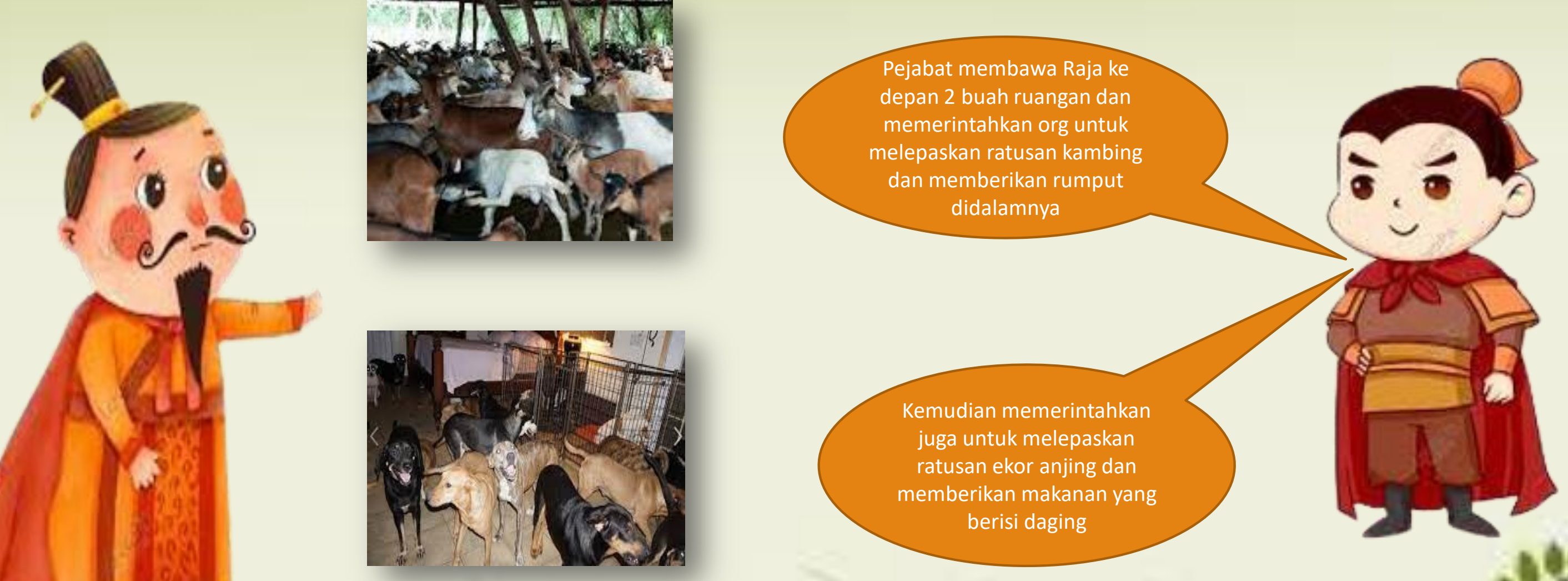

Kemudian memerintahkan

juga untuk melepaskan

ratusan ekor anjing dan berisi daging 


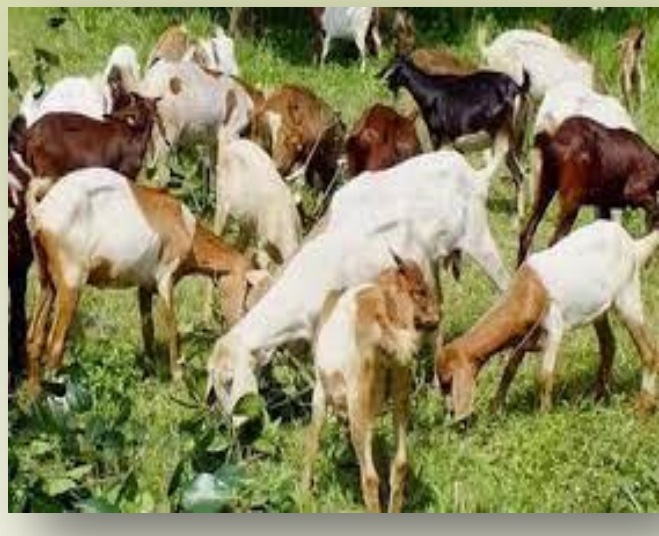

Kambing tetap makan bersama-sama kemudian berisitirahat bersama

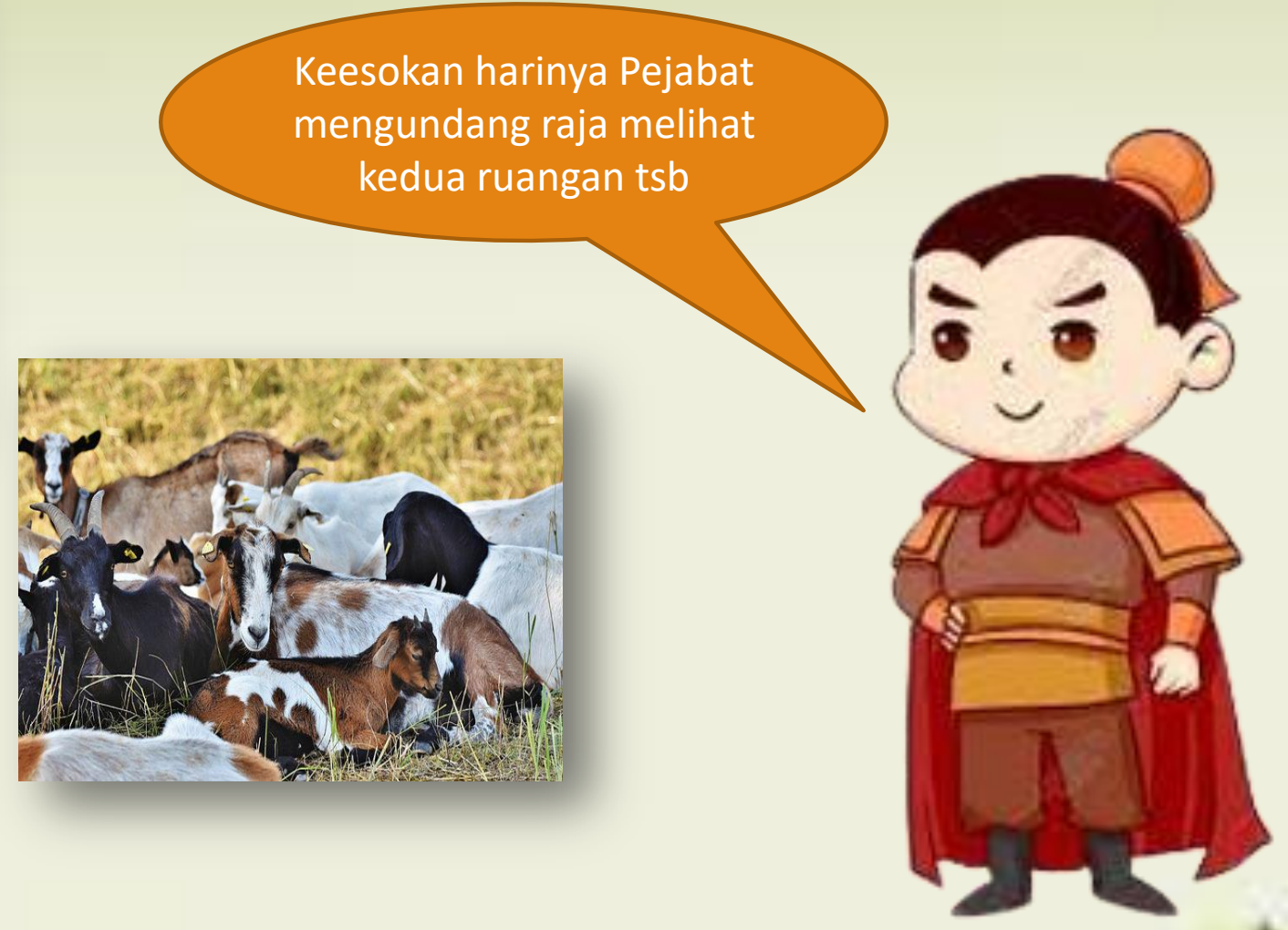


Raja terkejut melihat ruangan kedua, tercium bau amis darah, sebagian anjing

napasnya tinggal satu-satu dan makanannya tetap berada di tempatnya

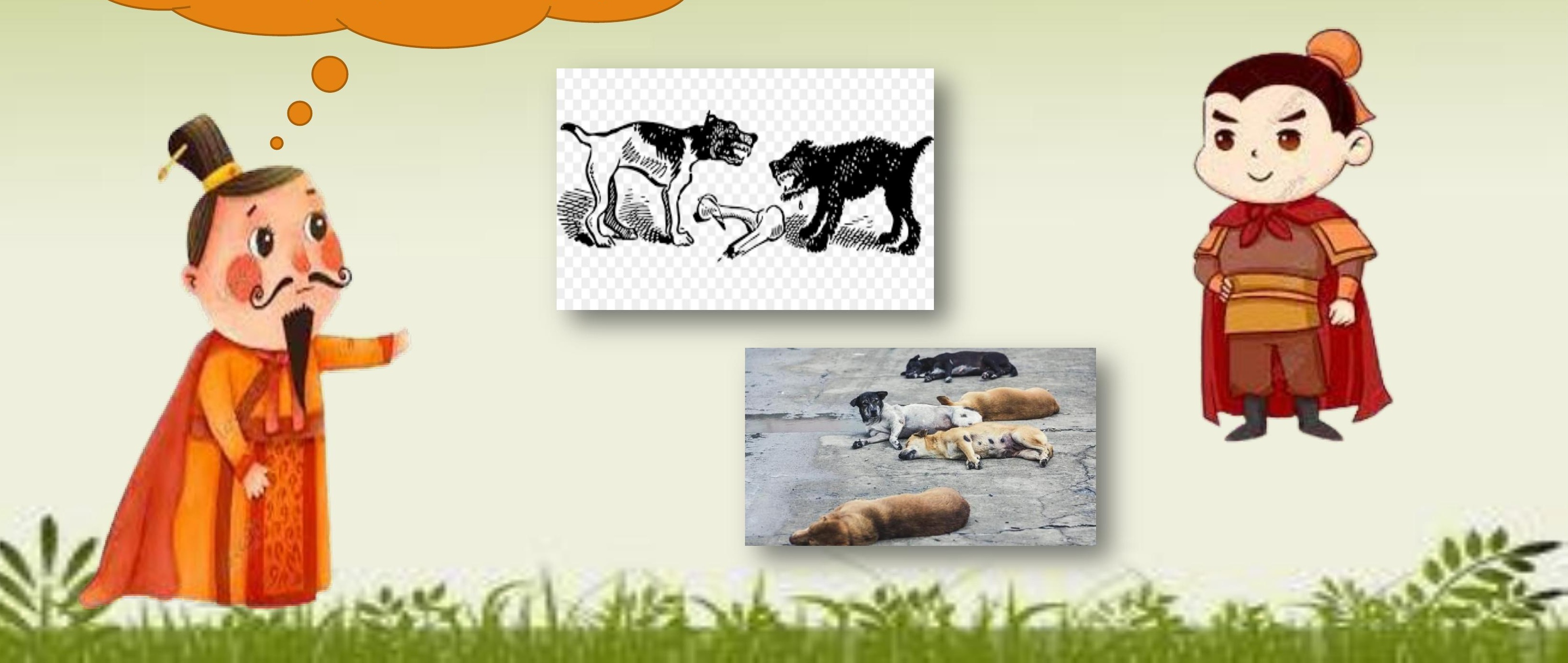




\section{KEBIJAKSANAAN YANG TERKANDUNG}

BEKERJA SAMA ADALAH SEBUAH PILIHAN CERDAS.

DENGAN BEKERJASAMA, BARULAH KITA BISA MENIKMATI KEHIDUPAN YANG TENTERAM.

SEDANGKAN BILA SALING BEREBUTAN, SALING BERMUSUHAN, BIASANYA HASIL AKHIRNYA ADALAH KEDUA PIHAK SAMA-SAMA TERLUKA

DIN MAN, 200 Kisah terindah Sepanjang Masa dari China

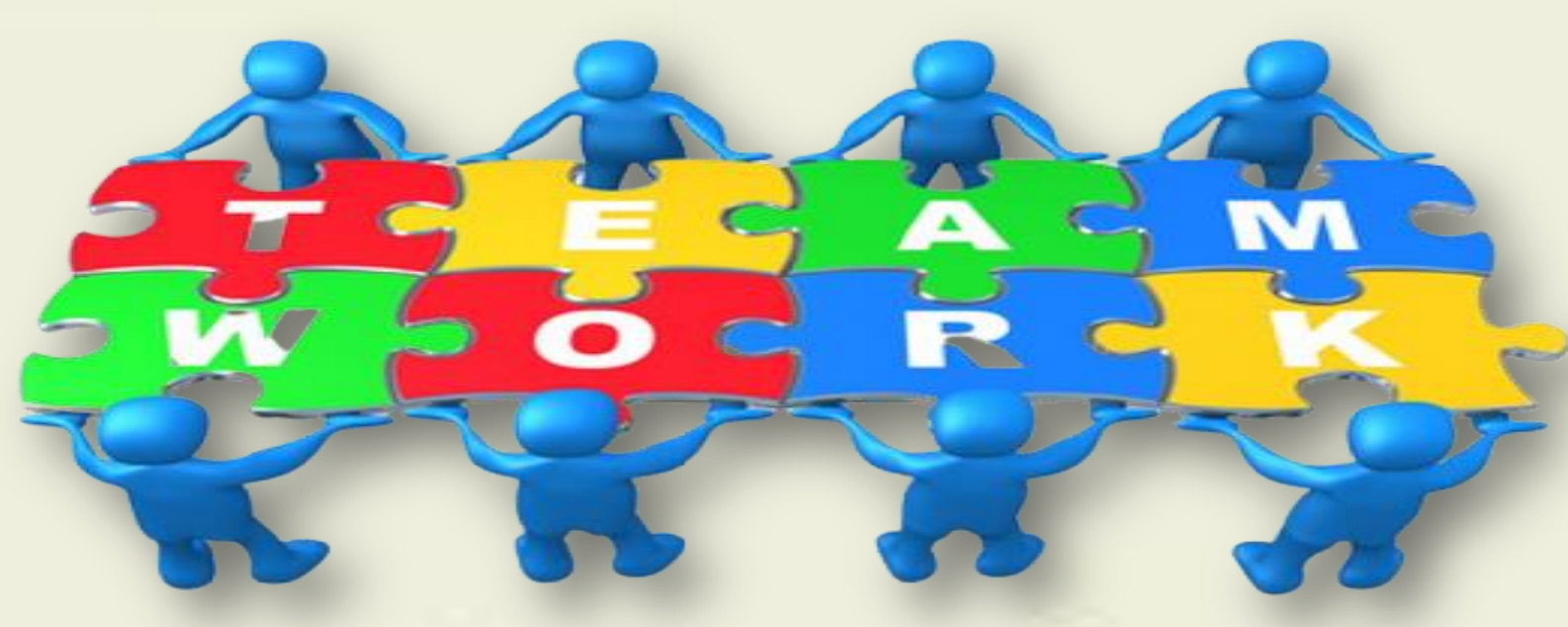




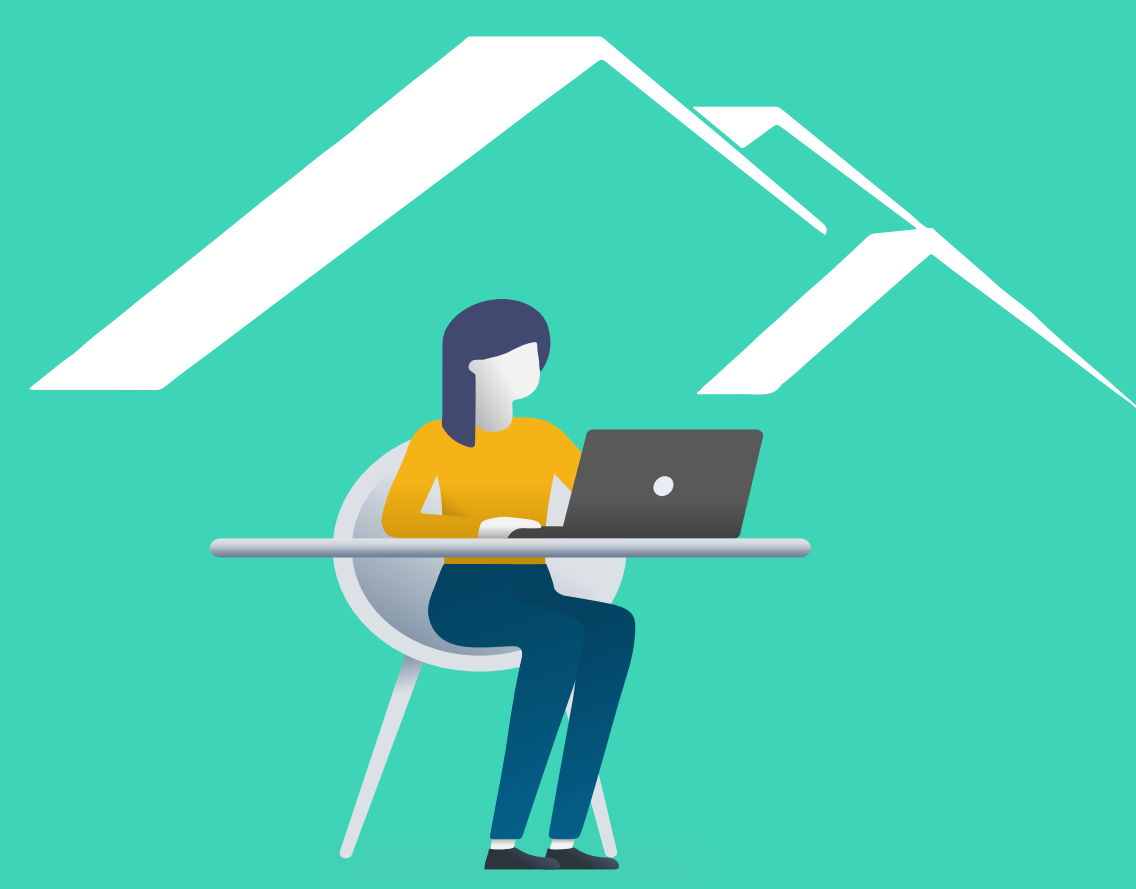

\section{ARE YOU READY FOR CHANGE ?}

\section{THANK YOU}

Disajikan pada Webinar Pendidikan dengan Tema:

Membangun Sumber Daya Manusia Unggul Berbasis Kepulauan Menuju Society 5.0

Sabtu, 11 Desember 2021 


\section{BAHAN BACAAN}

Agustang, A., \& Oruh, S. (2021). KESEJAHTERAAN PSIKOLOGIS (studi Pada Dewasa Madya Yang Belum Menikah Di Kota Makassar).

Akbar, H., Oruh, S., \& Agustang, A. (2021). Indeks Prediktif Kejadian Demam Berdarah Dengue (DBD) Berbasis Perilaku Sosial Masyarakat Di Kabupaten Indramayu. Jurnal Kesehatan, 14(2 SE-), 76-82. https://doi.org/10.32763/juke.v14i2.289

Mario, M., Oruh, S., \& Agustang, A. (2021). Pola Relasi: Kontrak Radikalisme Terhadap Perempuan Milenial. Jurnal Sosialisasi: Jurnal Hasil Pemikiran, Penelitian Dan Pengembangan Keilmuan Sosiologi Pendidikan, 8, 72-86.

Mukti, I., Oruh, S., \& Agustang, A. (2021). Efek Pemberitaan Kekerasan Di Media Sosial Terhadap Citra Negatif Kota Makassar. JISIP (Jurnal IImu Sosial Dan Pendidikan), 5(4).

Nismawati, N., Oruh, S., \& Agustang, A. (2021). Eksistensi Tari Kabasaran Pada Masyarakat Minahasa. Jurnal IImiah Mandala Education, 7(4).

Oruh, S. (2021). Analisis faktor Keaktifan Kader dalam Kegiatan Posyandu. Jurnal IImiah Kesehatan Sandi Husada, 10(1), 319-325.

Oruh, S., \& Agustang, A. (2019). Pengaruh Pengetahuan Keluarga, Stigma Masyarakat dan Kepatuhan Minum Obat Terhadap Kekambuhan Penyakit Gangguan Jiwa di Kota Makassar. 53(9). https://doi.org/10.1017/CBO9781107415324.004

Oruh, S., \& AGUSTANG, A. (2019). PENGARUH PENGETAHUAN KELUARGA, STIGMA MASYARAKAT DAN KEPATUHAN MINUM OBAT TERHADAP KEKAMBUHAN PENYAKIT GANGGUAN JIWA DI KOTA MAKASSAR.

Oruh, S., Agustang, A., \& Bagu, A. A. (2017). KEJADIAN HEROPNAM GANGGUAN JIWA DAN FAKTOR YANG MEMPENGARUHI PADA RUMAH SAKIT KHUSUS DAERAH DADI PROVINSI SULAWESI SELATAN.

Oruh, S., Agustang, A., \& Bagu, A. A. (2020). KEJADIAN HEROPNAM GANGGUAN JIWA DAN FAKTOR YANG MEMPENGARUHI PADA RUMAH SAKIT KHUSUS DAERAH DADI PROVINSI SULAWESI SELATAN.

Oruh, S., \& Nur, H. (2021). Perilaku Masyarakat Pesisir di Hutan Mangrove Desa Balangdatu Kabupaten Takalar. Phinisi Integration Review, 4(2), 292-300.

Oruh, S., Theresia, M., \& Agustang, A. (2019). KESEJAHTERAAN PSIKOLOGIS. Researchgate.Net.

Rajab, M. A., Oruh, S., \& Agustang, A. (2021). Persepsi Masyarakat Lokal terhadap Ekowisata Mangrove Kuri Caddi Desa Nisombalia Kabupaten Maros. Pepatudzu: Media Pendidikan Dan Sosial Kemasyarakatan, 17(2), 166-172.

Ramlafatma, R., Oruh, S., \& Agustang, A. (2021). Efektivitas Pendidikan Moral Dalam Pembentukan Karakter Siswa Di TK Islam Terpadu Asa Sumbawa. Jurnal IImiah Mandala Education, 7(4).

Sumitro, S., Oruh, S., \& Agustang, A. (2021). Eksistensi Nilai Sosial Budaya Ndeu Paki Oi Mbaru Pada Masyarakat Donggo Kabupaten Bima. Jurnal IImiah Mandala Education, 7(4). 
Suparman, Oruh, S., \& Agustang, A. (2021). Dinamika Sosial Kelompok Tani (Studi Kasus Petani Bawang Merah Desa perangian Kecamatan Baraka Kabupaten Enrekang). JIIP-Jurnal IImiah IImu Pendidikan, 4(6), 406-414.

Ufie, A., Oruh, S., \& Agustang, A. (2021). Maintaining Social Harmony Through Historical Learning Based on Local Wisdom of Indigenous Peoples in Maluku. Historia: Jurnal Pendidik Dan Peneliti Sejarah, $5(1), 31-40$.

Oruh, S. (2021, December 4). KAU MAU KEMANA (Refleksi Sosiologis terhadap Integritas Upaya Kesehatan Jiwa). https://doi.org/10.31219/osf.io/ut6ja

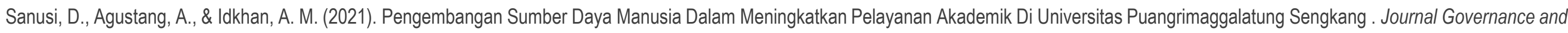
Politics (JGP), 1 (2 SE-Articles). https://jurnal.iyb.ac.id/index.php/jgp/article/view/205

Andriana, Agustang, A., Idkhan, A. M., \& Hasriadi. (2021). Daya Tanggap Pelayanan Unit Gawat Darurat di Puskesmas Sarjo Kabupaten Pasangkayu . Journal Governance and Politics (JGP), 1 (2 SEArticles). https://e-journal.iyb.ac.id/index.php/igp/article/view/201

Ardiansyah, A. A., \& Agustang, A. (2018). MAHASISWI BERKELUARGA DI FAKULTAS ILMU SOSIAL UNIVERSITAS NEGERI MAKASSAR. JURNAL SOSIALISASI, $19-23$.

Aris, Agustang, A., \& Idkhan, A. M. (2021). Efektifitas Pelayanan Aparatur Sipil Dalam Meningkatkan Pelayanan Publik. Journal Governance and Politics (JGP), $1(2$ SE-Articles).

https://jurnal.iyb.ac.id/index.php/igp/article/view/208

Arisal, A., Agustang, A., \& Syukur, M. (2020). Diskriminasi Sosial Anak Penderita Kusta di Kota Makassar. Phinisi Integration Review, 3(2), $297-304$.

Arpin, Agustang, A., \& Idkhan, A. M. (2021). Pengaruh Penerapan Model Dicovery Learning Terhadap Hasil Belajar Siswa Pada Mata Pelajaran IPA SD Inpres Tamalanrea V Kota Makassar. Journal Governance and Politics (JGP), 1(2 SE-Articles). https://e-journal.iyb.ac.id/index.php/igp/article/view/204

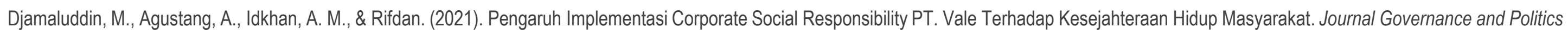
(JGP), 1 (2 SE-Articles). https://jurnal.iyb.ac.id/index.php/jgp/article/view/200

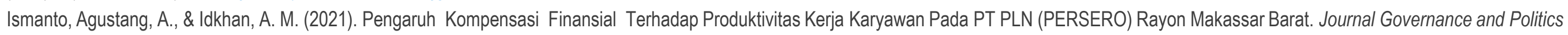
(JGP), 1 (2 SE-Articles). https://e-journal.iyb.ac.id/index.php/jgp/article/view/20

Mallappiang, N., Agustang, A., \& Idkhan, A. M. (2021). Keberadaan Humas Dalam Menunjang Tridharma Perguruan Tinggi Universitas Indonesia Timur Makassar. Journal Governance and Politics (JGP), 1(2), 134-148.

Nursafitra, M., Agustang, A., Idkhan, A. M., \& Nurwiwiana. (2021). Pengaruh Disiplin Kerja dan Komitmen Organisasi Terhadap Kinerja Pegawai di Kantor Dinas Kependudukan dan Pencatatan Sipil Kabupaten Enrekang. Journal Governance and Politics (JGP), 1 (2 SE-Articles). https://jurnal.iyb.ac.id/index.php/jgp/article/view/203

Sahabuddin, A., Agustang, A., \& Idkhan, A. M. (2021). Fungsi Leadership dalam Peningkatan Pelayanan Publik di Kantor Kecamatan Makassar. Journal Governance and Politics (JGP), 1(2 SE-Articles). https://jurnal.iyb.ac.id/index.php/jgp/article/view/207

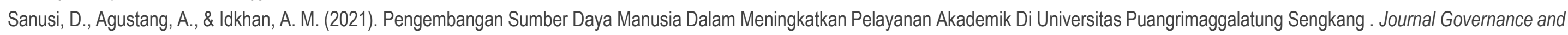
Politics (JGP), 1 (2 SE-Articles). https://jurnal.iyb.ac.id/index.php/jgp/article/view/205

Usman, A., Agustang, A., \& Idkhan, A. M. (2021). Penerapan Pelayanan Prima di Rumah Sakit Paru BBPM Makassar. Journal Governance and Politics (JGP), 1(2 SE-Articles).

https://jurnal.jyb.ac.id/index.php/jgp/article/view/206 